\title{
Effluent Quality of a Carbonated Soft Drink (CSD) Company in Owerri, Imo State, Nigeria and the Receiving Water Body
}

\author{
C.C. Ike ${ }^{1 *}$, E.G. Nwakwasi ${ }^{1}$, P.C. Emeka-Ike ${ }^{2}$, N.L. Nwakwasi ${ }^{3}$ and O.G. Nwogu ${ }^{4}$ \\ ${ }^{1}$ Department of Biological Sciences (Microbiology Programme), College of Basic and Applied \\ Sciences, Rhema University, P.M.B. 7021, Aba, Abia State, Nigeria \\ ${ }^{2}$ Department of Food Science and Technology, Imo State University, P.M.B. 2000, Owerri, \\ Imo State, Nigeria \\ ${ }^{3}$ Department of Civil Engineering, Federal University of Technology, P.M.B 1526, Owerri, \\ Imo State, Nigeria \\ ${ }^{4}$ Department of Food Science and Technology, Abia State Polytechnic, P.M.B. 7166, \\ Aba, Nigeria
}

*Corresponding author

\section{Keywords}

Effluent, Receiving water body,

Microbiological,

Physicochemical,

Pollution level

Article Info

Accepted:

12 September 2018

Available Online:

10 October 2018
A B S T R A C T

The effluent quality of a carbonated soft drink (CSD) company in Owerri and the receiving water body (Nworie River) were determined using standard microbiological and physicochemical methods. Microbial loads showed that total heterotrophic count (THC) ranged from $1.0 \times 10^{2} \pm 0.14$ to $3.7 \times 10^{5} \pm 0.53$ $\mathrm{CFU} / \mathrm{ml}$, total coliform count (TCC) ranged from $0.2 \times 10^{1} \pm 0.19$ to $2.9 \times 10^{5}$ $\pm 0.50 \mathrm{CFU} / \mathrm{ml}$ and yeast and mould count (Y\&MC) ranged from $1.1 \times 10^{2} \pm 0.1$ to $2.1 \times 10^{4} \pm 0.93 \mathrm{CFU} / \mathrm{ml}(\mathrm{p}<0.05)$. Six (6) bacterial isolates were identified to include Pseudomonas species, Bacillus species, Staphylococcus species, Escherichia coli, Flavobacterium species, and Azotobacter species, while six (6) fungal isolates were identified to include Aspergillus species, Penicillium species, Acremonium species, Rhodotorula species, Saccharomyces cerevisiae, and Candida species. Physicochemical results obtained in this study showed a pattern $(\mathrm{p}<0.05)$ with higher values recorded in the influent and least values in the effluent samples, while in the receiving water body, higher values were recorded in the discharge point, followed by downstream and least values in the upstream samples. However, it was discovered that discharges into the same tunnel from neighborhood companies around the industrial site increased the pollution level of the discharged effluent into the river, leaving potential effects on the downstream. Having considered the need for a sustainable water economy with looming water scarcity globally, and associated health hazards with untreated wastewater, there is need for proper monitoring by concerned agencies in ensuring wastewater from industries are treated to meet minimum permissible quality standards to avoid midstream contamination. 


\section{Introduction}

Nigeria is the most populous country in Africa with a population of over 160 million people; the country is endowed with generous resources of water bodies. This water provides resources for fishery, transportation, irrigation, recreation and domestic use (Ekiye and Luo, 2010). There are different regulations put in place to protect the marine environment and other water bodies in Nigeria. However, they have not been effective in controlling the indiscriminate dumping of effluent into open water bodies.

Inability to effectively and efficiently manage huge amount of wastes generated by various anthropogenic activities particularly in developing countries has created serious problems in our environment. Industrial effluent contamination of natural water bodies has emerged as a major challenge in developing and densely populated countries like Nigeria (Sangadoyin, 1995). River systems are the primary means for disposal of waste, especially the effluents, from industries that are near them. These effluent from industries have a great deal of influence on the pollution of the water body, these effluent can alter the physical, chemical and biological nature of the receiving water body (Sangadoyin, 1991). Increased industrial activities have led to pollution stress on surface waters both from industrial, agricultural and domestic sources (Ajayi and Osibanjo, 1981). The manner at which industrial effluents are being disposed into the environment (water bodies) like rivers, streams, etc. are becoming worrisome.

Over the years, in many African countries a considerable population growth has taken place, accompanied by a steep increase in urbanization and industrialization. This has led to tremendous increase in discharge of wide diversity of pollutants to receiving water bodies (Saad et al., 1985). The discharge of industrial effluents into receiving water bodies in Nigeria invariably result in the presence of high concentrations of pollutant in the water and sediment. The pollutants have been present in concentrations, which may be toxic to different organisms. The effluents also have considerable negative effects on the water quality of the receiving water bodies and as such, they are rendered unsafe for human use (Nwokorie and Ike, 2016; Kanu and Achi, 2011). The consequences of these negative effects are of great health concern (Osibanjo et al., 2011). One of the most important factors of water pollution is the microbial contamination, especially with pathogenic microorganisms. Enteric pathogens are typically responsible for several waterborne sicknesses (Sabae, 2004). However, these water bodies as in the case of developing countries like Nigeria serve as major source of water for domestic uses. The inhabitants depend on this available source for their daily drinking water and other activities like washing of clothes, bathing, etc. (Sangadoyin, 1995). Ideally, effluents from industries are to be properly treated before being discharged into the environment. In Nigeria, the case is different as there are many sharp practices by industrialists in managing effluent. Therefore, this study is targeted to assess the effluent quality of a carbonated soft drink company in Owerri and the receiving water body (Nworie River).

\section{Materials and Methods}

\section{Study area}

The study area is Owerri-West Local Government Area, in Owerri, Imo State, Nigeria. The geographical coordinates are $5.1215^{\circ} \mathrm{N}$, and $7.3732^{\circ} \mathrm{E}$. The area is of tropical climatic conditions with rain forest features. The soil type is silt-clay and the weather is typical of rain forest, with average 
annual temperature ranging between 25 and $35^{\circ} \mathrm{C}$ as lowest and highest values, respectively.

\section{Sample sources and collection}

Samples were collected from five (5) different sampling points which include Wastewater Treatment Plant (WWTP) and receiving water body (Nworie River). Two out of the five sampling points (influent and effluent) were from the wastewater treatment plant (also known as Effluent Treatment Plant - ETP), while the other three samples (upstream, discharge point and downstream) were from specified points in the receiving water body. Samples were collected in duplicate from the five sampling points. These samples were packaged aseptically for microbiological and physicochemical analysis. Universal sample bottles (sterile) of $100 \mathrm{ml}$ and $1000 \mathrm{ml}$ capacities were used for microbiological and physicochemical sampling respectively. The samples were transported in an icebox with sufficient ice blocks to maintain temperature of about $4-6^{\circ} \mathrm{C}$. The samples were then stored at $4^{\circ} \mathrm{C}$ at the refrigerator in the laboratory until use. All wastewater samples for microbiological analysis were analyzed within twenty four (24) hours after collection. The water samples for physicochemical analysis were analyzed within one (1) week of collection.

\section{Microbiological studies}

Tenfold serial dilutions of samples were done using sterile peptone water as the diluent. Spread plate and streaking techniques were used to enumerate and isolate bacteria and fungi in the samples (Cappucino and Sherman, 2010). Sample dilutions were prepared by adding $1.0 \mathrm{ml}$ of wastewater stock sample to $9.0 \mathrm{ml}$ of the sterile peptone water with vigorous agitation in ensuring adequate disengagement of microorganisms to obtain
$10^{-1}$ dilution. Serial dilutions of the homogenates were continued aseptically and made stepwisely till the sixth (6th) tube, to obtain dilutions of $10^{-3}$ to $10^{-6}$ dilutions and appropriate dilutions were plated in replicates using plate count agar for mean aerobic bacteria enumeration and isolation, tergitol agar for coliform enumeration and isolation, fortified sabouraud dextrose agar (SDA) for fungal enumeration and isolation. Pure bacterial isolates were identified using cultural, morphological and biochemical characterization. Identification of the bacteria to genera level was based on the schemes of Boone et al., (2005). The purified fungal isolates were identified on the basis of macroscopic and microscopic characteristics by slide culture technique, and lactophenol staining. The schemes of Barnet and Hunter (2000) and Watanabe (2010) were used for the identification. The plates were incubated at 35 $\pm 2{ }^{\circ} \mathrm{C}$ for 72 hours and 24 hours for total bacterial and coliform counts respectively and $25 \pm 2{ }^{\circ} \mathrm{C}$ for 120 hours for fungal counts.

\section{Physicochemical studies}

All the physicochemical parameters namely: appearance (apparent colour), odour, colour (true colour units), temperature ${ }^{0} \mathrm{C}$ (in situ), differential temperature (discharge \& stream), $\mathrm{pH}$, turbidity (NTU), conductivity $(\mu \mathrm{s} / \mathrm{cm})$, total hardness $\left(\mathrm{CaCO}_{3}\right) \mathrm{mg} / \mathrm{l}$, dissolved oxygen (DO) $\mathrm{mg} / \mathrm{l}$, total solid $\mathrm{mg} / \mathrm{l}$, total suspended solids (TSS) mg/l, total dissolved solids (TDS) $\mathrm{mg} / \mathrm{l}$, biochemical oxygen demand $\left(\mathrm{BOD}_{5}\right)$ $\mathrm{mg} / \mathrm{l}$, chemical oxygen demand (COD) $\mathrm{mg} / \mathrm{l}$, acidity $\left(\mathrm{CaCO}_{3}, \mathrm{mg} / \mathrm{l}\right)$, alkalinity $\left(\mathrm{CaCO}_{3}\right.$, $\mathrm{mg} / \mathrm{l}$ ), chloride $\mathrm{mg} / \mathrm{l}$, nitrate $\left(\mathrm{NO}_{3}{ }^{-}\right) \mathrm{mg} / \mathrm{l}$, sulphate (as $\mathrm{SO}_{4}{ }^{2-}$ ) $\mathrm{mg} / \mathrm{l}$, total phosphorus $\mathrm{mg} / \mathrm{l}$, free chlorine $\mathrm{mg} / \mathrm{l}$, chromium (hexavalent) $\mathrm{mg} / \mathrm{l}$, lead $\mathrm{mg} / \mathrm{l}$, nitrogen total $\mathrm{mg} / \mathrm{l}$, nickel $\mathrm{mg} / \mathrm{l}$, aluminum $\mathrm{mg} / \mathrm{l}$, manganese $\mathrm{mg} / \mathrm{l}$, cadmium $(\mathrm{mg} / \mathrm{l})$, cobalt $\mathrm{mg} / \mathrm{l}$, copper $\mathrm{mg} / \mathrm{l}$, total chromium $\mathrm{mg} / \mathrm{l}$, zinc $\mathrm{mg} / \mathrm{l}$, ammonia as nitrogen $\mathrm{mg} / \mathrm{l}$, Iron $\mathrm{mg} / \mathrm{l}$, calcium 
$\mathrm{mg} / \mathrm{l}$, magnesium $\mathrm{mg} / \mathrm{l}$, oil and grease $\mathrm{mg} / \mathrm{l}$, surfactants reacting to methylene blue were determined using methods described in CBM (2001) and WTM (1999).

\section{Data analysis}

Analysis of variance (ANOVA) was employed in this work and used to analyze all data obtained from the determinations. Descriptive statistics in form of mean and standard deviation and Duncan post hoc were also used to assess the data. The analyses were done using (Statistical Product and Service Solutions) SPSS 16.

\section{Results and Discussion}

The microbial diversity associated with a carbonated soft drink (CSD) wastewater in Owerri (influent and effluent) and the receiving water body - Nworie river (upstream, discharge point, and downstream) are shown in Table 1. From the results obtained, all the microbial counts enumerated were higher in the influent (THC- $2.0 \times 10^{5} \pm$ $0.87^{\mathrm{a}}$, TCC $-1.3 \times 10^{5} \pm 0.35^{\mathrm{a}}$, Y\&MC- $1.5 \times$ $10^{5} \pm 0.35^{\mathrm{a}}$ ) and lower in the effluent (THC$1.0 \times 10^{2} \pm 0.14^{\mathrm{e}}$, TCC- $0.2 \times 10^{1} \pm 0.19^{\mathrm{e}}$, Y\&MC- $\left.1.1 \times 10^{2} \pm 0.10^{\mathrm{d}}\right)$. There were significant differences $(\mathrm{p}<0.05)$ in microbial counts among the various groups: CSD wastewater (influent and effluent) and the receiving water body (upstream, discharge point and downstream).

In the receiving water body - the river, there were significant differences $(\mathrm{p}<0-05)$ among the samples (upstream - THC- $3.7 \times 10^{5} \pm$ $0.53^{\mathrm{ab}}$, TCC- $2.9 \times 10^{5} \pm 0.50^{\mathrm{ab}}$, Y\&MC- $2.1 \times$ $10^{4} \pm 0.93^{\mathrm{b}}$, discharge point - THC- $4.8 \times 10^{3} \pm$ $0.31^{\mathrm{d}}$, TCC- $2.1 \times 10^{2} \pm 0.18^{\mathrm{d}}$, Y\&MC- $1.4 \mathrm{x}$ $10^{2} \pm 1.02^{\mathrm{d}}$, and downstream - THC- $2.1 \mathrm{x}$ $10^{4} \pm 0.22^{\mathrm{c}}$, TCC- $1.9 \times 10^{4} \pm 0.47^{\mathrm{c}}$, Y\&MC$\left.2.2 \times 10^{3} \pm 0.66^{c}\right)$. However, no significant difference $(\mathrm{p}>0-05)$ between effluent sample $\left(1.1 \times 10^{2} \pm 0.10^{\mathrm{d}}\right)$ and that of discharge point $\left(1.4 \times 10^{2} \pm 1.02^{\mathrm{d}}\right)$ under yeast and mold counts.

The results of the physicochemical parameters namely: appearance (apparent colour), odour, colour (true colour units), temperature ${ }^{0} \mathrm{C}$ (in situ), differential temperature (discharge and stream), $\mathrm{pH}$, turbidity (NTU), conductivity $(\mu \mathrm{s} / \mathrm{cm})$, total hardness $\left.\left(\mathrm{CaCO}_{3}\right), \mathrm{mg} / \mathrm{l}\right)$, dissolved oxygen (DO) $\mathrm{mg} / \mathrm{l}$, total solid $\mathrm{mg} / \mathrm{l}$, total suspended solids (TSS) $\mathrm{mg} / \mathrm{l}$, total dissolved solids (TDS) $\mathrm{mg} / \mathrm{l}$, biochemical oxygen demand $\left(\mathrm{BOD}_{5}\right) \mathrm{mg} / \mathrm{l}$, chemical oxygen demand (COD) mg/l, acidity $\left(\mathrm{CaCO}_{3}\right.$, $\mathrm{mg} / \mathrm{l})$, alkalinity $\left(\mathrm{CaCO}_{3}, \mathrm{mg} / \mathrm{l}\right)$, chloride $\mathrm{mg} / \mathrm{l}$, nitrate $\left(\mathrm{NO}_{3}{ }^{-}\right) \mathrm{mg} / \mathrm{l}$, sulphate (as $\mathrm{SO}_{4}{ }^{2-}$ ) $\mathrm{mg} / \mathrm{l}$, total phosphorus $\mathrm{mg} / \mathrm{l}$, free chlorine $\mathrm{mg} / \mathrm{l}$, chromium (hexavalent) $\mathrm{mg} / \mathrm{l}$, lead $\mathrm{mg} / \mathrm{l}$, nitrogen total $\mathrm{mg} / \mathrm{l}$, nickel $\mathrm{mg} / \mathrm{l}$, aluminum $\mathrm{mg} / \mathrm{l}$, manganese $\mathrm{mg} / \mathrm{l}$, cadmium (mg/l), cobalt $\mathrm{mg} / \mathrm{l}$, copper $\mathrm{mg} / \mathrm{l}$, total chromium $\mathrm{mg} / \mathrm{l}$, zinc $\mathrm{mg} / \mathrm{l}$, ammonia as nitrogen $\mathrm{mg} / \mathrm{l}$, Iron $\mathrm{mg} / \mathrm{l}$, calcium mg/l, magnesium mg/l, oil and grease $\mathrm{mg} / \mathrm{l}$, surfactants reacting to methylene blue of the various sample groups were clearly tabulated in Table 2. Some of the results obtained from influent samples were above permissible limits (odour - unpleasant, $\mathrm{pH}$ $9.73 \pm 1.02^{\mathrm{a}}$, turbidity $-10.00 \pm 0.02^{\mathrm{a}}$, alkalinity $-218.65 \pm 1.02^{\mathrm{a}}$, biochemical oxygen demand $-67.32 \pm 1.07^{\mathrm{a}}$. chemical oxygen demand $-110.10 \pm 0.22^{\mathrm{a}}$, total dissolved solids $-750.09 \pm 0.02^{\mathrm{a}}$, total suspended solids $-32.15 \pm 0.09^{\mathrm{a}}$ and nitrate $16.02 \pm 0.02^{\mathrm{a}}$ except for heavy metals. All other sample groups (effluent, upstream, discharge point and downstream) had their entire results within permissible limits $(\mathrm{p}<0.05)$. The influent from the carbonated soft drink (CSD) wastewater in Owerri was polluted to the extent that most microbiological and physicochemical parameters were significantly high $(\mathrm{p}<0.05)$ and could be attributed to the heavy discharges from the various operational units within the factory. 
Table.1 Bioloads of a carbonated soft drink (CSD) wastewater (influent and effluent) and the receiving water body - Nworie river (upstream, discharge point, and downstream)

\begin{tabular}{|l|c|c|c|c|c|}
\hline MICROBES & \multicolumn{5}{|c}{ COUNT (CFU/ml) } \\
\cline { 2 - 7 } & INFLUENT & EFFLUENT & UPSTREAM (US) & DISCHARGE POINT (DP) & DOWNSTREAM (DS) \\
\hline THC & $2.0 \times 10^{5} \pm 0.87^{\mathrm{a}}$ & $1.0 \times 10^{2} \pm 0.14^{\mathrm{e}}$ & $3.7 \times 10^{5} \pm 0.53^{\mathrm{ab}}$ & $4.8 \times 10^{3} \pm 0.31^{\mathrm{d}}$ & $2.1 \times 10^{4} \pm 0.22^{\mathrm{c}}$ \\
\hline TCC & $1.3 \times 10^{5} \pm 0.35^{\mathrm{a}}$ & $0.2 \times 10^{1} \pm 0.19^{\mathrm{e}}$ & $2.9 \times 10^{5} \pm 0.50^{\mathrm{ab}}$ & $2.1 \times 10^{2} \pm 0.18^{\mathrm{d}}$ & $1.9 \times 10^{4} \pm 0.47^{\mathrm{c}}$ \\
\hline Y\&MC & $1.5 \times 10^{5} \pm 0.35^{\mathrm{a}}$ & $1.1 \times 10^{2} \pm 0.10^{\mathrm{d}}$ & $2.1 \times 10^{4} \pm 0.93^{\mathrm{b}}$ & $1.4 \times 10^{2} \pm 1.02^{\mathrm{d}}$ & $2.2 \times 10^{3} \pm 0.66^{\mathrm{c}}$ \\
\hline
\end{tabular}

Values are given as mean \pm SD (standard deviation). Within rows, values followed by the same alphabets are not significantly different but those followed by different alphabets are significantly different. Legend: THC $=$ Total heterotrophic count, $\mathrm{CC}=$ Coliform count, $\mathrm{Y} \& \mathrm{MC}=$ Yeast and mold count. NESREA, (2009).

Table.2 Physicochemical results of a carbonated soft drink (CSD) wastewater (influent and effluent) and the receiving water body - Nworie river (upstream, discharge point, and downstream)

\begin{tabular}{|c|c|c|c|c|c|c|}
\hline \multirow[t]{2}{*}{$\mathbf{S} / \mathbf{N}$} & \multirow[t]{2}{*}{ PARAMETERS } & \multicolumn{5}{|c|}{ RESULTS OF ANALYSIS } \\
\hline & & Influent & Effluent & Upstream (US) & Discharge point (DP) & Downstream (DS) \\
\hline & PHYSICO-CHEMICAL TESTS: & & & & & \\
\hline 1. & Appearance (apparent colour) & Slightly cloudy & Clear & Slightly clear & Slightly clear & Slightly clear \\
\hline 2. & Odour & Unpleasant & Odourless & Odourless & Odourless & Odourless \\
\hline 3. & Colour (True colour units) & $15.00 \pm 0.89^{\mathrm{a}}$ & $3.00 \pm 0.16^{\mathrm{b}}$ & $7.00 \pm 0.43^{c}$ & $6.00 \pm 0.08^{c}$ & $7.00 \pm 0.21^{\mathrm{c}}$ \\
\hline 4. & Temperature ${ }^{0} \mathrm{C}$ ( in situ) & $28.70 \pm 0.07^{\mathrm{a}}$ & $25.40 \pm 0.22^{b}$ & $26.90 \pm 0.04^{\mathrm{bc}}$ & $27.20 \pm 0.60^{c}$ & $27.04 \pm 0.17^{\mathrm{c}}$ \\
\hline 5. & Differential Temperature (Discharge \& stream) & & $1.64 \pm 0.14^{\mathrm{a}}$ & & & \\
\hline 6. & $\mathrm{pH}$ & $9.73 \pm 1.02^{\mathrm{a}}$ & $7.90 \pm 0.09^{b}$ & $8.28 \pm 1.02^{\mathrm{c}}$ & $8.56 \pm 0.31^{\mathrm{c}}$ & $8.43 \pm 0.05^{\mathrm{c}}$ \\
\hline 7. & Turbidity NTU & $10.00 \pm 0.02^{\mathrm{a}}$ & $4.00 \pm 0.21^{\mathrm{b}}$ & $5.04 \pm 0.99^{c}$ & $5.27 \pm 0.65^{\mathrm{c}}$ & $5.16 \pm 0.72^{\mathrm{c}}$ \\
\hline 8. & Conductivity $(\mu \mathrm{s} / \mathrm{cm})$ & $1277 \pm 0.66^{\mathrm{a}}$ & $832 \pm 0.50^{b}$ & $506.90 \pm 0.14^{\mathrm{d}}$ & $919.02 \pm 0.66^{\mathrm{c}}$ & $596.40 \pm 0.70^{\mathrm{d}}$ \\
\hline 9. & Total Hardness $\left.\left(\mathrm{CaCO}_{3}\right), \mathrm{mg} / \mathrm{l}\right)$ & $62.50 \pm 0.89^{\mathrm{a}}$ & $50.0 \pm 0.91^{\mathrm{b}}$ & $47.50 \pm 0.16^{\mathrm{c}}$ & $60.03 \pm 0.11^{\mathrm{d}}$ & $49.62 \pm 0.53^{b}$ \\
\hline 10. & Dissolved Oxygen (DO) mg/l & $2.89 \pm 0.16^{\mathrm{de}}$ & $3.75 \pm 0.11^{\mathrm{bc}}$ & $5.07 \pm 0.09^{\mathrm{a}}$ & $3.15 \pm 0.74^{\mathrm{d}}$ & $4.08 \pm 0.22^{b}$ \\
\hline 11. & Total Solid mg/l & $812.03 \pm 0.45^{\mathrm{a}}$ & $426.07 \pm 0.71^{\mathrm{c}}$ & $304.90 \pm 0.05^{\mathrm{de}}$ & $486.32 \pm 0.65^{b}$ & $331.55 \pm 0.81^{\mathrm{d}}$ \\
\hline 12. & Total Suspended Solids (TSS) mg/l & $32.15 \pm 0.09^{\mathrm{a}}$ & $10.53 \pm 0.03^{b c}$ & $6.34 \pm 0.20^{\mathrm{d}}$ & $13.41 \pm 0.19^{\mathrm{b}}$ & $6.49 \pm 0.04^{\mathrm{d}}$ \\
\hline 13. & Total Dissolved Solids (TDS) mg/l & $750.09 \pm 0.02^{\mathrm{a}}$ & $405.04 \pm 0.07^{\mathrm{c}}$ & $214.01 \pm 0.02^{\mathrm{e}}$ & $457.06 \pm 0.12^{b}$ & $289.22 \pm 0.17^{\mathrm{d}}$ \\
\hline 14. & Biochemical Oxygen Demand $\left(\mathrm{BOD}_{5}\right) \mathrm{mg} / \mathrm{l}$ & $67.32 \pm 1.07^{\mathrm{a}}$ & $33.7 \pm 0.66^{\mathrm{c}}$ & $25.12 \pm 0.30^{\mathrm{d}}$ & $40.3 \pm 0.07^{b}$ & $31.10 \pm 0.42^{\mathrm{c}}$ \\
\hline 15. & Chemical Oxygen Demand (COD) mg/l & $110.10 \pm 0.22^{\mathrm{a}}$ & $56.50 \pm 0.52^{b}$ & $37.33 \pm 0.23^{\mathrm{cd}}$ & $58.17 \pm 0.18^{\mathrm{b}}$ & $41.25 \pm 0.10^{c}$ \\
\hline 16. & Acidity $\left(\mathrm{CaCO}_{3}, \mathrm{mg} / \mathrm{l}\right)$ & $35.00 \pm 0.64^{\mathrm{a}}$ & $17.50 \pm 0.88^{\mathrm{c}}$ & $15.58 \pm 0.54^{\text {cd }}$ & $19.01 \pm 0.65^{\mathrm{b}}$ & $17.50 \pm 0.43^{\mathrm{c}}$ \\
\hline 17. & Alkalinity $\left(\mathrm{CaCO}_{3}, \mathrm{mg} / \mathrm{l}\right)$ & $218.65 \pm 1.02^{\mathrm{a}}$ & $120.07 \pm 0.99^{b}$ & $114.60 \pm 0.76^{\mathrm{bc}}$ & $122.04 \pm 0.12^{b}$ & $119.55 \pm 0.66^{\mathrm{b}}$ \\
\hline 18 & Chloride $\mathrm{mg} / \mathrm{l}$ & $54.12 \pm 1.01^{\mathrm{a}}$ & $50.02 \pm 1.20^{\mathrm{a}}$ & $26.59 \pm 0.19^{\mathrm{bc}}$ & $54.90 \pm 0.14^{\mathrm{a}}$ & $38.67 \pm 1.01^{\mathrm{b}}$ \\
\hline 19. & Nitrate $\left(\mathrm{NO}_{3}^{-}\right) \mathrm{mg} / \mathrm{l}$ & $16.02 \pm 0.02^{\mathrm{a}}$ & $4.83 \pm 0.33^{\mathrm{c}}$ & $3.20 \pm 0.09^{\mathrm{cd}}$ & $5.62 \pm 0.22^{\mathrm{b}}$ & $4.45 \pm 0.03^{\mathrm{c}}$ \\
\hline 20. & Sulphate (as $\left.\mathrm{SO}_{4}{ }^{2-}\right) \mathrm{mg} / \mathrm{l}$ & $79.91 \pm 0.55^{\mathrm{a}}$ & $71.00 \pm 0.87^{\mathrm{c}}$ & $26.00 \pm 0.55^{\mathrm{e}}$ & $75.05 \pm 0.66^{b}$ & $40.50 \pm 0.08^{\mathrm{d}}$ \\
\hline 21. & Total Phosphorus mg/l & $0.80 \pm 0.06^{\mathrm{a}}$ & $0.53 \pm 0.12^{\mathrm{b}}$ & $0.21 \pm 0.18^{\mathrm{cd}}$ & $0.59 \pm 0.05^{\mathrm{b}}$ & $0.33 \pm 0.04^{c}$ \\
\hline 22. & Free Chlorine mg/l & $0.25 \pm 0.02^{\mathrm{a}}$ & ND & ND & ND & ND \\
\hline 23. & Chromium (hexavalent) mg/l & $0.003 \pm 0.55^{\mathrm{a}}$ & $0.001 \pm 0.19^{\mathrm{a}}$ & BDL & $0.001 \pm 0.13^{\mathrm{a}}$ & BDL \\
\hline 24. & Lead $\mathrm{mg} / \mathrm{l}$ & $0.002 \pm 0.04^{\mathrm{a}}$ & $0.001 \pm 0.05^{\mathrm{a}}$ & ND & $0.001 \pm 0.02^{\mathrm{a}}$ & BDL \\
\hline 25. & Nitrogen Total mg/l & $10.63 \pm 0.12^{\mathrm{a}}$ & $6.18 \pm 0.47^{\mathrm{b}}$ & $1.22 \pm 0.02^{\mathrm{de}}$ & $4.18 \pm 0.47^{\mathrm{c}}$ & $2.60 \pm 0.64^{d}$ \\
\hline 26. & Nickel mg/l & $0.003 \pm 0.01^{\mathrm{a}}$ & $0.002 \pm 0.11^{\mathrm{a}}$ & BDL & $0.001 \pm 0.31^{\mathrm{a}}$ & BDL \\
\hline 26. & Aluminum mg/l & $0.04 \pm 0.09^{\mathrm{a}}$ & $0.02 \pm 0.15^{\mathrm{ab}}$ & BDL & $0.01 \pm 0.14^{\mathrm{c}}$ & BDL \\
\hline 28. & Manganese mg/l & $0.01 \pm 0.02^{\mathrm{a}}$ & $0.01 \pm 0.10^{\mathrm{a}}$ & BDL & $0.005 \pm 0.13^{\mathrm{b}}$ & BDL \\
\hline 29. & Cadmium (mg/l) & $0.24 \pm 0.13^{\mathrm{a}}$ & $0.11 \pm 0.05^{\mathrm{b}}$ & BDL & $0.005 \pm 0.82^{c}$ & $\mathrm{BDL}$ \\
\hline 30. & Cobalt mg/l & $0.003 \pm 0.22^{\mathrm{a}}$ & $0.001 \pm 0.41^{\mathrm{b}}$ & BDL & $0.001 \pm 0.19^{b}$ & BDL \\
\hline 31. & Copper mg/l & $0.13 \pm 0.76 a$ & $0.11 \pm 0.42 \mathrm{a}$ & BDL & $0.005 \pm 0.05 b$ & BDL \\
\hline 32. & Total Chromium mg/l & $0.37 \pm 0.44^{\mathrm{a}}$ & $0.21 \pm 0.76^{\mathrm{b}}$ & BDL & $0.01 \pm 0.54^{\mathrm{c}}$ & BDL \\
\hline 33. & Zinc $\mathrm{mg} / \mathrm{l}$ & $0.12 \pm 0.03^{\mathrm{a}}$ & $0.10 \pm 0.01^{\mathrm{a}}$ & BDL & $0.005 \pm 0.10^{c}$ & $\mathrm{BDL}$ \\
\hline 34. & Ammonia as Nitrogen $\mathrm{mg} / \mathrm{l}$ & $0.24 \pm 0.55^{\mathrm{a}}$ & $0.18 \pm 0.34^{b}$ & BDL & $0.01 \pm 0.22^{\mathrm{c}}$ & $\mathrm{BDL}$ \\
\hline 35. & Iron $\mathrm{mg} / \mathrm{l}$ & $0.02 \pm 0.21^{\mathrm{a}}$ & $0.01 \pm 0.19^{\mathrm{a}}$ & BDL & $0.01 \pm 0.10^{\mathrm{a}}$ & BDL \\
\hline 36. & Calcium mg/l & $32.21 \pm 0.77^{\mathrm{a}}$ & $20.06 \pm 0.55^{\mathrm{c}}$ & $9.04 \pm 0.31^{\mathrm{d}}$ & $25.12 \pm 0.28^{b}$ & $11.45 \pm 0.11^{\mathrm{d}}$ \\
\hline 37. & Magnesium mg/l & $68.24 \pm 0.22^{\mathrm{a}}$ & $61.92 \pm 0.87^{b}$ & $16.32 \pm 0.20^{\mathrm{de}}$ & $58.80 \pm 0.15^{\mathrm{bc}}$ & $21.03 \pm 0.65^{\mathrm{d}}$ \\
\hline 38. & Oil and Grease mg/l & $4.30 \pm 1.06^{\mathrm{a}}$ & ND & ND & ND & ND \\
\hline 39. & Surfactants reacting to methylene blue & $2.24 \pm 0.02^{\mathrm{b}}$ & $2.62 \pm 1.18^{\mathrm{a}}$ & $0.52 \pm 0.15^{\mathrm{e}}$ & $2.12 \pm 0.78^{\mathrm{bc}}$ & $1.01 \pm 0.21^{\mathrm{d}}$ \\
\hline
\end{tabular}

Values are given as mean \pm SD (standard deviation). Within rows, values followed by the same alphabets are not significantly different but those followed by different alphabets are significantly different. Legend: ND $=$ Not Detected, BDL = Below Detection Limit, NESREA, (2009). 
The high values recorded in total dissolved solids and suspended solids were as a result of spills and discharges of chemicals during operations. Some of these pollutants served as nutrient to most inherent degrading microbes. The sugar spills from the syrup room were major source of carbon to inhabiting microorganisms. This contributed to the high bioloads recorded in the results. According to Osibanjo et al., (2011); Gray (2009); and, Ekhaise and Ayansi (2005) the high microbial loads reflected the level of pollution in the environment which indicates the amount of organic matter and toxic substances present. The results obtained in this study correlated with the assertion of Osibanjo et al., (2011); Gray (2009); and, Ekhaise and Ayansi (2005).

Microorganisms obtained in this study include bacteria: Pseudomonas species, Bacillus species, Staphylococcus species, Escherichia coli, Flavobacterium species, Azotobacter species, and fungi: Aspergillus species, Penicillium species, Acremonium species, Rhodotorula species, Saccharomyces cerevisiae, Candida species. The microbes obtained in this study were in agreement with the research reports of Nwokorie and Ike (2016) and Ibekwe et al., (2004).

The presence of coliforms in the carbonated soft drink (CSD) wastewater samples (influent and effluent) could be traced to poor sanitary practices among workers in the plant and is an indication of fecal contamination, while that of the receiving water body (upstream and downstream) could be due to either discharges into the river and/or from activities of users of the stream. Activities of the river/ stream users include swimming, washing of clothes, bathing, and the crude practice of urinating and defeacating into water body. During rainy season, the run offs from stormwater equally contributes to the contamination evidenced with receiving water body. The presence of Escherichia coli in wastewater discharges is an indication of poor sanitary conditions in the practice of personal hygiene in food safety environment and could lead to faecal contamination of products. Bacillus, Pseudomonas, Flavobacterium and Azotobacter species are known to be environmental contaminants and can be found in the air, water and soil, while Staphylococcus aureus is known to inhabit the human skin as an opportunistic microorganism. Bacillus species are known as spore formers and can withstand harsh weather conditions. The presence of Aspergillus, Penicillium, Acremonium and Rhodotorula species could be attributed to the surrounding environment (Ike et al., 2015). Saccharomyces cerevisiae was associated with sugar and sugar fermentations. The activities of making syrup resulting in sugar spills encouraged the replication of Saccharomyces cerevisiae. Also, beverage product spills and bursts during filling at the filler could contribute to sugar concentrations in the wastewater. Sugar is a major source of carbon, and as a nutritional element encourages growth of various groups of microorganisms including the degrading aerobes.

The $\mathrm{pH}$ of the influent was slightly alkaline (9.73 \pm 1.02$)$ and above set regulatory standard (NESREA) due to discharges of caustic soda during bottle washing and cleaning of process lines. It was discovered that $\mathrm{pH}$ values sometimes could shoot up to 10.26 during the monthly dumping of caustic from the washing machine. This adversely affects the microbial community and could be remedied by addition of hydrochloric acid at the equalization tank to neutralize the alkaline condition. When optimal $\mathrm{pH}$ is achieved, it encourages microbial activities especially in replication and degradation of organic matter to facilitate settleability of flocks as sludge to produce clear effluent. This was observed in the physicochemical results obtained in 
sample of discharged effluent which invariably has met permissible limits as recommended by NESREA, and recorded in Table 2.

However, due to negative activities around the neighborhoods by some companies in the same industrial site that uses the same underground sewer tunnel in discharging their wastewater, it was observed that such discharges had significant pollution impact on the regulated discharges from the carbonated soft drink (CSD) company as evidenced in the discharge point (DP) sample results. These polluted discharges have seriously marred the concerted efforts of the CSD company in context, in maintaining wholesome effluent discharge requirements as recommended by NESREA. The after effect of these pollutions could range from pathogenic microbes (Okoh, 2007), eutrophication, depletion of oxygen (Kanu and Achi, 2011) to fouling of the water body (Osibanjo et al., 2011). These could create unconducive environment with unnecessary stress that affects aquatic lives and exposes users to different health hazards/ water borne diseases as reported by Nwokorie and Ike (2016); Kanu and Achi (2011); Osibanjo et al., (2011); and Ekhaise and Ayansi (2005).

Having considered the need for a sustainable water economy with looming water scarcity globally, and associated health hazards with untreated wastewater, there is need for proper monitoring by concerned agencies in ensuring wastewater from industries are treated to meet minimum quality requirements for every intended use before they are discharged.

\section{References}

Ajayi, S. O., and Osibanjo, O. 1981. Pollution Studies on Nigerian Rivers, water quality of some Nigeria Rivers.
Environmental Pollution Series, 2:8795.

Barnet, H. L., and Hunter, B. B. 2000. Illustrated Genera of Imperfect Fungi. $3^{\text {rd }}$ Edition. Burgess Publishing Company. Minnesota, USA. pp 41-111.

Boone, D. R., Castenholz, R. W., Garrity, G. M., Brenner, D. J., Krieg, N. R., and Staley, J. R. (Eds.). 2005. Bergey's Manual of Systematic Bacteriology. Second Edition. New York: SpringerVerlag.

Cappucino, G. J. R. and Sherman, B. 2010. Microbiology: A Laboratory Manual, Nineth Edition. The Benjamin Publishing Coy. California.

Carbonated Beverage Manual - CBM. 2001. Carbonated beverage quality control manual, Volume I \&II: Standards and procedures - Analytical, Published by The Coca Cola Company (TCCC), Athens, pp 12-112.

Ekhaise, F. O., and Ayansi, C. C. 2005. Influence of breweries effluent discharge on the microbiological and physiochemical quality of Ikpoba River, Nigeria. African Journal of Biotechnology, 4: 1062 - 1065.

Ekiye, E. and Luo, Z. 2010. Water quality monitoring in Nigeria: Case study of Nigerian industrial cities. Journal of American Science, 6 (4): 22 - 28.

Gray, A. V. 2009. Case Study on Water Quality Modelling of Dianchi Lake, Yunnan Province, Southwest China. Water Science Technology, 40: 35-43.

Ibekwe, V. I., Nwaiwu, O. I., and Offorbuike, J. O. 2004. Bacteriological and physiochemical qualities of waste water from a bottling company in Owerri, Nigeria, Global Journal Environmental Science, 3: 51-54.

Ike, C. C., Emeka-Ike, P. C., Nwokorie, C. C., and Anochie, C. C. 2015. Microbiological Quality of Locally Prepared Snacks sold in Aba 
Metropolis, Abia State, Nigeria. International Journal of Scientific Engineering and Applied Science (IJSEAS), 1 (7): 46-59.

Kanu, I., and Achi, O. K. 2011. Industial effluents and their impact on water quality of receiving rivers in Nigeria. Journal of Applied Technology in Environmental Sanitation, 1 (1): 75 86.

NESREA, 2009. National Environmental Standards for Effluent Limitations and Regulation (Food, Beverages \& Tobacco Sector) Regulations, Published by The Federal Government Printer, Abuja, Nigeria, pp 1211- 1248.

Nwokorie, C. C., and Ike, C. C. 2016. The Physico-chemical and Microbial Contamination of Discharged Effluents on the Receiving Water Body. A Study of Brewery "A" in South-Eastern Nigeria. International Journal of Scientific Engineering and Applied Science (IJSEAS), 2(5): 208-216.

Okoh, A. I. 2007. Wastewater treatment plants as a source of microbial pathogens in the receiving watershed. African Journal of Biotechnology, 6 (25): 2932-2944.

Osibanjo, O., Dase, A. P., and Gbadebo, A. M. 2011. The impact of industries on surface water quality of River Ona and River Alaro in Oluyole Industrial
Estate, Ibadan, Nigeria. African Journal Biotechnology, 10:696-702.

Saad, M. A. H., McComas, S. R., and Eisenreich, S.J. 1985. Metals and chlorinated hydrocarbons in surficial sediments of three Nile Delta Lakes. Journal of Water, Air and Soil Pollution, 24: 27-33

Sabae, S. Z. 2004. Monitoring of microbial pollution in the River Nile and the mpact of some human activities on its waters. Proceeding of $3^{\text {rd }}$ International Conference on Biological Science, 3: 200-214.

Sangadoyin, A. Y. 1991. Ground water and surface water pollution by open refuse dump in Ibadan, Nigeria. Journal of discovery and innovations, 3(1): 24-31.

Sangadoyin, A. Y. 1995. Characteristics and control of industrial effluent. Genres ted pollution environmental management and health, 6(4): $15-18$.

Watanabe, T. 2010. Pictorial Atlas of Soil and Seed Fungi: Morphologies of Cultured Fungi and Key to Species, Third Edition. CRC Press. Pp. $211-376$.

Water Technology Manual "WTM", 1999. Standard methods for the examination of water and wastewater. $20^{\text {th }}$ Edition. Published jointly by American Public Health Association, American Water Works Association and Water Environment Federation, Washington DC. Pp. 5- 672.

\section{How to cite this article:}

Ike, C.C., E.G. Nwakwasi, P.C. Emeka-Ike, N.L. Nwakwasi and Nwogu, O.G. 2018. Effluent Quality of a Carbonated Soft Drink (CSD) Company in Owerri, Imo State, Nigeria and the Receiving Water Body. Int.J.Curr.Microbiol.App.Sci. 7(10): 1670-1677.

doi: https://doi.org/10.20546/ijcmas.2018.710.191 